\title{
Heavy Chain Disease
}

National Cancer Institute

\section{Source}

National Cancer Institute. Heavy Chain Disease. NCI Thesaurus. Code C3082.

A group of rare disorders of immunog lobulin synthesis associated with B-cell proliferative disorders. 